Снежана Милосављевић Милић ${ }^{1}$

Универзитет у Нишу

Филозофски факултет ${ }^{2}$

Департман за србистику
УДК 061.62:82.01(497.11 Ниш)

Осврт

Примљен: 10. јун 2021.

Прихваћен: 15. јун 2021.

DOI: https://doi.org/10.46630/gsrj.19.2021.27

\title{
ЦЕНТАР ЗА НАРАТОЛОШКЕ СТУДИЈЕ - ПРВИХ ПЕТ ГОДИНА РАДА
}

Центар за наратолошке студије Универзитета у Нишу формиран је 12. 10. 2016. године. Идеја за његово оснивање потекла је од професора и сарадника Департмана за српску и компаративну књижевност Филозофског факултета. Оснивањем Центра Универзитет у Нишу постао је прва институција на балканским просторима која има овакву научну јединицу у свом саставу, аналогно наратолошким центрима у западној Европи. Његови чланови су наставници и сарадници Филозофског факултета а руководилац Центра је редовни професор др Снежана Милосављевић Милић.

Наратолошка истраживања су изразито мултидисциплинаран подухват који повезује различите научне области: од друштвено-хуманистичких (наука о књижевности, лингвистика, историја, психологија, студије медија филозофија, естетика), преко природних и примењених наука (бионауке, геонауке, медицина), до техничких наука (софтверски инжињеринг, теорије вештачке интелигенције).

Центар за наратолошке студије координира и руководи следећим активностима:

- обједињује истраживања различитих профила у оквиру наратолошких истраживања,

- конципира и реализује истраживачке пројекте из области наратолошких истраживања и наратолошких студија,

- организује, сам или у сарадњи са другим научним институцијама, сарадњу између истраживача различитих основних дисциплина

- capaђује са другим центрима за наратолошке студије у региону и иностранству на заједничким пројектима,

- организује предавања угледних гостију из земље, региона и иностранства, кроз физичка гостовања или преко видео-линка,

- организује конференције, симпозијуме, саветовања, округле столове, радионице и летње школе из области наратологије, за истраживаче, раднике универзитета, студенте и ширу јавност,

\footnotetext{
${ }^{1}$ snezana.milosavljevic.milic@filfak.ni.ac.rs

${ }^{2}$ Рад је настао у оквиру интерног пројекта Србистика на Филозофском факултету у Нишу, Филозофског факултета у Нишу, чији је руководилац проф. др Надежда Јовић.
} 
- у у оквиру пројеката, ангажује студенте докторских студија заинтересоване за наратолошка истраживања, а нарочито стипендисте Министарства науке, просвете и технолошког развоја, који имају обавезу учешћа на пројектима,

- објављује публикације из области наратолошких истраживања,

- ради на промоцији научних активности Филозофског факултета и Универзитета у Нишу у земљи и иностранству.

Чланови Центра су од свог оснивања објавили већи број стручних публикација - монографија, уџбеника и зборника радова, међу којима најзначајније место припада међународном тематском вишејезичном зборнику радова From Narrative to Narrativity / Od narativa do narativnosti (ur. S. Milosavljević Milić, J. Jovanović, M. Bojanić Ćirković, Niš, 2018) међу чијим сарадницима су неки од најеминентнијих наратолога данашњице: Моника Флудерник, Мари-Лор Рајан, Волф Шмид, Валериј Тјупа.

Центар за наратолошке студије је од свог оснивања организовао предавања угледних стручњака са академских институција из иностранства (Центар за типологију и семиотику Руског државног универзитета за хуманистичке науке у Москви), као и са Универзитета у Београду, Крагујевцу и Нишу. Посебно издвајамо тематска предавања из области Студија сећања и Трансмедијалних студија.

Планом рада предвиђено је да се у току лета 2022. године у организацији Центра за наратолошке студије одржи по први пут Летња наратолошка школа, међународна манифестација која би окупила студенте из региона и света, као и угледне наратологе у својству предавача. 